\title{
Funeral Picketing Laws and Free Speech
}

\author{
Stephen R. McAllister
}

\section{INTRODUCTION}

"Thank God For Dead Soldiers." "Soldiers Die God Laughs." "Thank God For IEDs." "God Is Your Enemy." "Semper Fi, Semper Fags, coming home in body bags." "Don't Worship The Dead." "Thank God For 9/11." These are just a sampling of the phrases that have appeared on signs or been chanted near military funerals and memorial services across the nation the past year by a small group of now notorious protesters. ${ }^{1}$

Such statements are offensive to Americans - to put it mildly-even in the abstract. Place such words on pickets or in the mouths of protesters located near a funeral for an American soldier killed in Iraq or Afghanistan, and it may be difficult to imagine more outrageous and provocative speech. But members of the Westboro Baptist Church, located in Topeka, Kansas, have borne these messages time and again in just such settings. ${ }^{2}$ Their efforts have garnered national media attention,

Professor of Law, University of Kansas School of Law. I wish to thank specially Chris Steadham, Faculty Services Librarian at the University of Kansas School of Law, for his excellent research assistance in support of this Article and some of my other endeavors. And I wish to thank my wife, Suzanne, and our children, for their support and patience in hearing more about funeral picketing the past several months than anyone should be expected to endure.

In the interest of full disclosure, it should be noted that during spring 2006 I provided pro bono constitutional advice to committees of the Kansas legislature and the Kansas Revisor of Statutes on proposed amendments to the Kansas Funeral Picketing Act, and to members of the Senate Judiciary Committee of the United States Congress regarding federal proposals. Also, during the time I wrote most of this Article, I served as Legislative Counsel for Kansas (until March 7, 2007), but this Article represents only my personal views and thoughts about these issues. I am not writing in any official capacity.

1. There is, unfortunately, much more, with targets that include the President, the federal government, the Catholic Church, and even some nonmilitary deceased individuals. See The Westboro Baptist Church Home Page, http://www.godhatesfags.com/mainindex.html (last visited Feb. 24, 2007) (displaying the protest group's messages).

2. The group even proposed to picket the funeral of five Amish girls killed by a crazed gunman in the girls' schoolhouse, but apparently was persuaded to forego such an endeavor by a radio talk show host who gave them time on the air to espouse their views instead. Jacques Steinberg, Air Time Instead of Funeral Protest, N.Y. TiMES, Oct. 6, 2006, at A14. 
infuriated the American public, and caused elected officials to pass new laws to stop them.

Not surprisingly, Congress and many state legislatures have responded to the protesters by enacting laws designed to mute and conceal from mourners' sight the protesters and their provocative messages. These laws I will collectively refer to as "funeral picketing" acts, though some of them are not so titled and their application is not necessarily limited to either funerals or picketing. About forty states and the federal government now have such statutes, with several other states likely to enact them in the near future.

Although the funeral picketing laws vary in their details, most of them limit the times and locations for protest activities, frequently restricting such activities to areas outside some buffer zone surrounding the location of a funeral or memorial service during a certain period of time, usually from shortly before to shortly after such a service. Many also effectively define the protesters' activities as disorderly conduct prohibited by law, wherever it occurs.

The First Amendment prohibits any law "abridging the freedom of speech." 3 The protesters and several constitutional scholars argue that funeral picketing laws may infringe upon First Amendment free speech rights. ${ }^{4}$ In fact, lawsuits already have been filed challenging some of the state laws, including one in which a federal district judge declared the Kentucky law unconstitutional. ${ }^{5}$ The funeral picketing acts raise a new variation on an old theme in the Supreme Court's First Amendment free speech jurisprudence: to what extent may government prohibit or restrict speech that is extremely offensive in a particular setting?

This Article addresses funeral picketing legislation in three parts. Part II both briefly describes the protesters' activities that recently motivated so many legislatures to act and provides an overview of the

3. U.S. CONST. amend. I. The text applies the prohibition to Congress alone but, of course, the Supreme Court long has interpreted it to apply to the states as well, relying upon the incorporation doctrine the Court has developed as part of the Due Process Clause of the Fourteenth

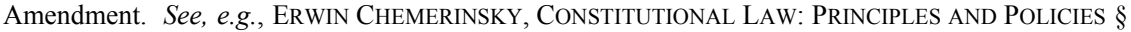
6.33, at 499-507 (3d ed. 2006) (noting that the First Amendment applies to the states by virtue of the Fourteenth Amendment); JOHN E. NOWAK \& RONALD D. ROTUNDA, PRINCIPLES OF CONSTituTiOnAL LAW $\S 10.2$, at 210-11 (2d ed. 2005) (same).

4. See, e.g., Ronald K.L. Collins \& David L. Hudson, Jr., A Funeral for Free Speech? Laws Against Funeral Protests Strike at the First Amendment, LeGAL TiMES, Apr. 17, 2006, at 66 (arguing the First Amendment protects funeral protests); Eugene Volokh, Burying Funeral Protests, NATIONAL REVIEW, Mar. 3, 2006, http://www.nationalreview.com/comment/volokh200603230730 .asp (arguing that picketing near a funeral is protected speech).

5. See McQueary v. Stumbo, 453 F. Supp. 2d 975, 992-97 (E.D. Ky. 2006) (holding that the Kentucky statute was unconstitutionally broad and not narrowly tailored). 
federal and state laws recently enacted. Part III addresses several important constitutional questions that funeral picketing laws raise. Part IV discusses some of the problems - both philosophical and pragmaticthat confront legislative bodies attempting to navigate constitutional free speech territory in the funeral picketing context.

Ultimately, measures that fully satisfy outraged lawmakers and the general public may not withstand constitutional scrutiny, nor will laws that satisfy First Amendment requirements likely satisfy the public and their elected representatives. But that result is neither new nor unusual. The Supreme Court generally has been zealous in its protection of the First Amendment speech rights of all, reflecting an apparent longstanding and deeply held American commitment to free speech as a cornerstone of our society.

What seems relatively clear as a matter of constitutional law is that governments can regulate several aspects of funeral protests, including intrusive noise, impeding access, trespassing on private property, crowd size, and actual threats. But what is not so clear is whether governments can simply push protesters out of sight, define the mere display of offensive words as disorderly conduct, or enforce laws so as to punish the critics of war and our soldiers while tolerating messages supporting war and our troops.

Notwithstanding constitutional scholars, lawyers, courts, and the complexities of the First Amendment, sometimes there may be no better advice than the childhood adage that "sticks and stones may break our bones but words will never hurt us"-if we do not let them. But, of course, words can and do hurt us emotionally. Nonetheless, the Supreme Court has been very reluctant to conclude that words cause legally compensable harm, and with good reason. Difficult as it may be, in the long run the best response to the funeral protesters may be to ignore them. Ironically, the protesters likely would have given up their activities long ago had they not generated such an incredible response from so many lawmakers across America. And they certainly would not have the opportunity to recover potentially substantial sums in attorney's fees from government entities that enact and enforce laws purporting to restrict what may well be the protesters' constitutionally protected activities. 


\section{FUnERAL PICKETING ORIGINS AND RECENT ENACTMENTS}

\section{A. The Funeral Picketers: The Westboro Baptist Church}

Few protesters in the United States in recent years can match the provocative and hateful messages conveyed by the members of the Westboro Baptist Church in Topeka, Kansas. Apparently founded by a former lawyer, Fred Phelps, the church consists primarily-if not exclusively - of the extended Phelps family. ${ }^{6}$ The church meets regularly, and for about fifteen years has been sending members to public locations, often during events such as graduations or lectures, to convey the church's messages. ${ }^{7}$ The church's predominant message is one of virulent antihomosexuality; most of its other messages are variations on that theme or extend from it. ${ }^{8}$

The church's members have engaged in the picketing of funerals for several years, including the funerals of AIDS victims and notably of Wyoming murder victim Matthew Shepard several years ago. Lately, the church has chosen to picket the funerals of members of the armed services killed in Afghanistan and Iraq. The typical protest involves a handful of church members standing across the street from the funeral with pickets bearing their messages. Sometimes, the protesters also sing or chant songs (sometimes well-known hymns or songs with the church's own "lyrics") or slogans, with or without the use of loudspeakers or amplification devices.

The Westboro Baptist Church is no stranger to law nor litigation. Several of its members are trained as attorneys, and some apparently have current law licenses. The church appears not to believe in civil disobedience, and its members appear to go to lengths not to be arrested when they engage in protests. Instead, the protesters appear to comply with law enforcement instructions regarding a protest, such as directions to remain in a certain location during a funeral or to refrain from using

6. Apparently, Fred and Marge Phelps have thirteen children, nine of whom are active in the church, along with approximately forty grandchildren. Several years ago a University of Kansas School of Journalism professor wrote an extensive chapter on the Phelps family and their antihomosexual protest activities. Rick Musser, Fred Phelps Versus Topeka, in Culture WARS \& LOCAL POLITICS 158 (Elaine B. Sharp ed., 1999).

7. Indeed, I have considerable personal experience with the group, having witnessed their protests at numerous events at the University of Kansas, in Lawrence, Kansas, including annual protests at the hooding ceremony for graduates of the School of Law.

8. I hesitate to give the church any more attention, but their own website better demonstrates what the funeral picketers and their messages are about than any description I can write. For that website address, see supra note 1. 
loudspeakers or making significant noise. That said, the church and its members are not afraid to bring suit in court challenging restrictions placed on their protest activities. Currently, they are being represented by the American Civil Liberties Union in at least a couple of cases challenging the constitutionality of funeral picketing laws.

\section{B. Funeral Picketing Laws}

With about forty state funeral picketing laws and an Act of Congress now on the statute books, one must be careful in generalizing or lumping these enactments together as a group. There are commonalities among the laws, but also some variations that may be of constitutional significance.

\section{State Funeral Picketing Acts}

Since January 2006, approximately forty states have enacted or amended funeral picketing laws (some had relevant preexisting laws) and a dozen more have considered or are currently considering such laws. ${ }^{9}$ The level of state legislative activity is remarkable, since forty-five states would be more than enough to ratify a constitutional amendment. It is not an easy matter to get ninety percent of the states simultaneously to pursue new legislation addressing a specific, nonfederal problem, especially without the motivation of losing federal funding if no action is taken. ${ }^{10}$ The scope of state activity speaks volumes about the American public's reaction to the funeral picketers.

9. See Table 1, infra Part VI. Table 1 is current to the best of the author's ability, but with many states actively considering new laws or amendments to existing laws throughout the spring of 2007, it is difficult to be completely current. Further, Table 1 first was created in late fall, 2006, focusing primarily on legislative activity during the spring and summer of 2006 . Because many state legislatures are in session primarily, if not solely, during the spring, much additional activity is taking place as this Article goes to print. Thus, some states that failed to enact laws in the spring of 2006 , now either have done so in the spring of 2007, or are actively considering new proposed legislation. Some states, including Kansas, had a relevant statute prior to 2006, but either amended or considered amending their earlier enactments, typically to strengthen and to clarify such laws' prohibitions.

By the author's count, as of March 15, 2007, about forty states have enacted new or amended pre-existing laws, and others have considered or are currently considering funeral picketing law proposals.

10. Spending power legislation is a way that Congress sometimes induces all states to enact particular legislation, such as Megan's Laws requiring sex offender registration and notification. Stephen R. McAllister, Megan's Laws: Wise Policy or Ill-Conceived Public Folly?, 7 KAN. J. L. \& PUB. Policy 1, 1 n.8 (1998); Stephen R. McAllister, "Neighbors Beware": The Constitutionality of State Sex Offender Registration and Community Notification Laws, 29 TEX. TECH L. REV. 97, 101 (1998). 
The state statutes embody three approaches to the funeral picketing situation. First, most of the state laws restrict the locations available for protesting and the time period during which such locations are restricted. In other words, the laws create buffer zones around funerals and memorial services, generally during a specified time period, such as an hour before to an hour following such services. The buffer zones range in size from 100 feet $^{11}$ to 1000 feet, ${ }^{12}$ with the most common zones being $300^{13}$ or 500 feet. $^{14}$ Of course, state legislatures have to define where the buffer zone begins, and usually they have opted for the boundary of or entrances to the property on which a funeral is held. Only a handful of states have chosen not to include a buffer zone as part of a funeral picketing law. ${ }^{15}$

A second approach, much less common than buffer zones, but consistent with the historical police power approach to regulating protests, is to define funeral picketing as disorderly conduct that is generally prohibited under state law and to prohibit the disruption of funerals through noise or other means. Such laws prohibit altogether protest activities that disturb the peace or disrupt a service, without reference to any defined buffer zone. Thus, some laws effectively prohibit the protesters from using megaphones or amplification equipment, or engaging in loud singing or yelling even without amplification, if it in any way interferes with a service. A few states appear to have considered or enacted laws relying solely on the "disorderly conduct" or "disruption" approach. ${ }^{16}$

11. E.g., Colo. Rev. STAT. §§ 13-21-126, 18-9-101, -106(3), -107(3), -108(2), -117, -125 (2006); Md. Code AnN., CRIM. LAW § 10-205 (LexisNexis Supp. 2006); VT. STAT. ANN. tit 13, § 3771 (Westlaw through 2005-2006 Sess.).

12. E.g., MinN. STAT. § 609.501 (2003 \& Supp. 2007); Miss. Code ANN. § 97-35-18 (West, Westlaw through 2006 Reg. Sess. and 2d Ex. Sess.); S.C. CODE ANN. § 16-17-525 (Supp. 2006); S.D. CODIFIED LAWS $\S \S 22-13-17$ to -20 (2006).

13. Thirteen states have, or proposed, 300 -foot buffer zones. See Table 1, infra Part VI.

14. Nineteen states have, or proposed, 500-foot buffer zones. See Table 1, infra Part VI.

15. Only seven states have, or proposed, no buffer zone. Typically, they rely instead upon defining the picketers' activity as disorderly conduct prohibited anywhere. See, e.g., FLA. STAT. $\S \S$ 871.01-.02 (West, Westlaw through ch. 1 of 2007 Spec. 'A' Sess.); LA. REV. STAT. ANN. § 14:103 (2004 \& Supp. 2007); S. 342, 2007 Gen. AssemB., Reg. SESS. (R.I. 2007); H.R. 5124, 2007 Gen. AssemB., REG. SeSS. (R.I. 2007); VA. CODE ANN. § 18.2-415 (Westlaw through 2006 Spec. Sess.) Missouri has two laws - the first enacted to prohibit the picketing "in front of or about" a funeral. MO. REV. STAT. $§ 578.501$ (Supp. 2007). Apparently realizing that the constitutionality of such language had been questioned in prior cases, the Missouri legislature enacted a "fallback" bill which includes a 300-foot buffer zone. MO. REV. STAT. $\$ 578.502$ (Supp. 2007).

16. See, e.g., Fla. Stat. § 871.01 (“disturbing” approach); LA. Rev. Stat. AnN. § 14:103 (disturbing the peace); VA. CODE ANN. § 18.2-415; S.B. 342, 2007 Gen. Assemb., Reg. Sess. (R.I. 2007) (disturbing the peace). 
Several states have enacted or considered laws that adopt a third approach, which is to combine the first two. Thus, most states that have enacted funeral picketing laws have adopted both a buffer zone and a prohibition on the disruption of services through noise or other means. In other words, disrupting a service is defined as disorderly conduct, usually even when the conduct at issue occurs outside any applicable buffer zone. ${ }^{17}$ This is essentially the approach that Congress adopted in the federal law discussed in the next subpart.

2. The Respect for America's Fallen Heroes Act and the Respect for the Funerals of Fallen Heroes Act

On Memorial Day, 2006, President Bush signed into law the Respect for America's Fallen Heroes Act. ${ }^{18}$ The law applies to "cemeteries under the control of the National Cemetery Administration and at Arlington National Cemetery." ${ }^{19}$ It prohibits demonstrations on such property unless approved by the superintendent or director of the same. ${ }^{20}$ Importantly, it also restricts "demonstrations" (as defined in the statute, see below) "during the period beginning 60 minutes before and ending 60 minutes after a funeral, memorial service, or ceremony" in the following ways: such "demonstrations" cannot (1) be "within 150 feet of a road, pathway, or other route of ingress to or egress from such cemetery property" and include "willfully making or assisting in the making of any noise or diversion that disturbs or tends to disturb the peace or good order of the funeral, memorial service, or ceremony," or (2) be "within 300 feet of such cemetery" if it "impedes the access to or egress from such cemetery." 21

17. E.g., Ala. Code § 13A-11-17 (Supp. 2006); Colo. Rev. STAT. §§ 18-9-106(3), -125 (2006); Del. CodE ANN. tit. 11, § 1303 (Westlaw through 76 Laws 2007 ch. 3); GA. CodE ANN. § 16-11-34.2 (2003 \& Supp. 2006); 720 Ill. COMP. STAT. 5/26-6 (West, Westlaw through P.A. 94-1 of 2007 Reg. Sess.); IND. CODE § 35-45-1-3 (Westlaw through 2006 2d Reg. Sess.); IOWA CODE $§ 723.5$ (West, Supp. 2007); KAN. STAT. ANN. § 21-4015 (2006); KY. REV. STAT. ANN. § 525.055, .060, .145, .155 (West, Westlaw through 2006 Reg. Sess. and 1st Spec. Sess.) 2006); MD. CodE ANN., CRIM. LAW $§ 10-205$ (LexisNexis Supp. 2006).

18. Pub. L. No. 109-228, § 1, 120 Stat. 387. The entire Act is included as Appendix A to this Article. See infra Part VII (containing the text of H.R. 5037 which was signed into law by the President in May, 2006).

19. $§ 2,120$ Stat. at 387 .

20. Id. § $2(\mathrm{a})(1)(\mathrm{a})(1)$.

21. Id. $\S 2(\mathrm{a})(1)(\mathrm{a})(2)$. 
[T] he term 'demonstration' includes the following: $:^{22}$

(1) Any picketing or similar conduct.

(2) Any oration, speech, use of sound amplification equipment or device, or similar conduct that is not part of a funeral, memorial service, or ceremony.

(3) The display of any placard, banner, flag, or similar device, unless such a display is part of a funeral, memorial service, or ceremony.

(4) The distribution of any handbill, pamphlet, leaflet, or other written or printed matter other than a program distributed as part of a funeral, memorial service, or ceremony.

The federal act provides that whoever violates it "shall be fined under this title, imprisoned for not more than one year, or both." ${ }^{24}$ It also states that "[i]t is the sense of Congress that each State should enact legislation to restrict demonstrations near any military funeral." ${ }^{, 5}$

The federal act follows common traits of the many state laws that preceded it. Among other things, it sets a time limit for its restrictions to apply (one hour before to one hour after a funeral), it creates buffer zones around routes of ingress to and egress from funerals, and it prohibits noise "or diversion" that disrupts a service within the 150 -foot buffer zone. The federal act also provides examples of what constitutes "demonstrations" subject to the law's restrictions, though it does not purport to be a definitive statement, instead indicating only that restricted or prohibited actions include the list set forth in the statute.

On December 22, 2006, the President signed into law the "Respect for the Funerals of Fallen Heroes" Act, ${ }^{26}$ which amends the previous law in one significant way: the amendment makes the federal law applicable to "any funeral of a member or former member of the Armed Forces that is not located at a cemetery under the control" 27 of the federal government. Otherwise, the amendment generally tracks the buffer zone provisions and definitions of the earlier federal enactment. But it would appear that this more recent federal act to some extent makes

22. $I d . \S 2(\mathrm{a})(1)(\mathrm{b})$.

23. $I d$.

24. Id. §3(a).

25. $I d . \S 4$.

26. Pub. L. No. 109-464, $\S 1,120$ Stat. 3480 . The entire Act is included in Appendix B to this Article. See infra Part VIII.

27. $\S 1(a), 120$ Stat. at 3480 . 
unnecessary many of the state legislative efforts, at least with respect to funeral picketing at military funerals. The newer federal act does not, of course, purport to apply to funeral picketing in other contexts, and the Westboro Baptist Church has in fact picketed or threatened to picket at nonmilitary funerals, so in those circumstances, state laws would place the only restrictions on the picketers.

The federal acts differ from many of the state laws in several ways. To the extent the federal law applies to federally controlled cemeteries (the original Respect for America's Fallen Heroes Act), it is much narrower in scope than most state laws. The Respect for the Funerals of Fallen Heroes amendments, however, dramatically expand the scope of the federal acts to cover military funerals wherever held. In that respect, the federal law now has very broad scope, and produces the irony (perhaps) that in many instances, funeral picketing that is not prohibited by the federal law (because it is more than 150 or 300 feet away from the designated locations) may nonetheless violate state law, or vice versa in the few instances where states have adopted a smaller buffer zone.

Unlike most of the state laws, the federal acts define the buffer zones in large part by access to funerals and funeral locations, such as cemeteries; there is no buffer around portions of a federal cemetery where there is no ingress or egress road or pathway. Many of the state laws, by contrast, draw a buffer zone "bubble" completely around a funeral location, sweeping in all property within the bubble, irrespective of ingress or egress points. Also, the federal acts define the restricted or prohibited "demonstrations" with more specificity than many state laws.

\section{The CONSTITUTIONAL QUESTIONS THAT FUNERAL PICKETING LAWS RAISE}

Proponents of funeral picketing laws have articulated several arguments to justify limiting the activities of the Westboro Baptist Church. One argument is that targeted picketing - picketing that focuses on a particular location-should receive lesser constitutional protection. Another argument is that the mourners attending funeral or memorial services are a captive audience, allowing the government more leeway to regulate the protesters' speech. And yet another argument is that the protesters" messages are "fighting words" which receive no constitutional protection. Each of these defenses of funeral picketing laws finds its source in Supreme Court decisions, though the weight of Supreme Court precedent tends to undermine all three arguments.

Indeed, as further discussed below, it seems clear that the funeral picketing laws regulate constitutionally protected "speech." That said, as 
discussed below, it is also reasonable to conclude that the laws regulate the protesters' speech both because of the location where it takes place and the manner in which the message is conveyed - near funerals and by targeted picketing - rather than because of the messages' content.

If accurate, these conclusions have two possible important consequences. First, the funeral picketers are not wholly without constitutional protection, i.e., they are engaged in "speech," and speech that receives some level of constitutional shelter. ${ }^{28}$ But second, the federal and state laws do not necessarily target the picketers because of their messages. Rather, these laws on the whole appear to be both content and viewpoint neutral, an important constitutional issue discussed further below. The result of these two propositions- "speech" is at issue but the laws are content neutral - is that the constitutionality of funeral picketing acts likely will turn on the courts' application of the reasonably well-settled doctrine of time, place, and manner regulation, also discussed below.

This Article next addresses three primary questions in turn: (1) Are the funeral picketers engaged in constitutionally protected "speech?"; if so, (2) are the funeral picketing laws "content" and "viewpoint" neutral?; and if so, (3) are funeral picketing laws constitutionally valid time, place, and manner regulations?

\section{A. Is Funeral Picketing Constitutionally Protected "Speech?"}

Not every action a person takes is expressive nor counts as "speech" for constitutional purposes. Nor is it quite the case (yet, anyway) that Americans can say anything, anytime, anywhere, to anyone, without regard for governmental restrictions or fear of legal consequences. Nor is all speech treated the same under the Supreme Court's First Amendment jurisprudence.

Indeed, some categories of speech-such as fighting words, ${ }^{29}$ obscenity, ${ }^{30}$ and commercial speech $^{31}$-receive lesser or (in theory

28. One scholar posits that the Supreme Court's free speech cases can be characterized essentially as embodying a fundamental legal rule as follows: "Citizens possess an enforceable right to speak openly about political, social, and moral issues and to receive the perspectives of others without inessential constraint." Brian C. Murchison, Speech and the Self-Governance Value, 14 WM. \& MARY BILL RTS. J. 1251, 1253 (2006). Of course, in the funeral picketing context, no one is arguing to protect their right to "receive" the protesters' messages, but the protesters themselves are - in their own unique, provocative, and offensive way-commenting on political, social, and moral issues.

29. Chaplinsky v. New Hampshire, 315 U.S. 568, 572-73 (1942).

30. See, e.g., New York v. Ferber, 458 U.S. 747, 766 n.18 (1982) (child pornography); Roth v. 
anyway) no constitutional protection. And circumstances and audience may matter, be the situation one of a "captive audience" that cannot avoid the message, ${ }^{32}$ an educational setting that involves school children, ${ }^{33}$ or a symbol of hatred and intimidation that has terrorized a segment of the American population for generations. ${ }^{34}$ Further, even conduct that courts acknowledge has an expressive character or purpose is not necessarily given the same constitutional status as traditional, political speech. ${ }^{35}$

\section{Targeted Picketing}

The funeral picketing laws vary in their descriptions of the regulated activity, though many focus on picketing. Certainly, picketing in general is speech (by definition, carrying a sign with a message), but that alone may not determine whether the Constitution prohibits government from restricting or banning picketing in certain contexts. In fact, the courts have recognized generally that targeted picketing may raise concerns apart from any message that picketers are attempting to convey. ${ }^{36}$ And targeted picketing generally seems to be the activity the funeral picketing laws primarily address.

United States, 354 U.S. 476, 484-85 (1957) (obscenity).

31. 44 Liquormart, Inc. v. Rhode Island, 517 U.S. 484, 498 (1996); Cent. Hudson Gas \& Elec. Corp. v. Pub. Serv. Comm'n, 447 U.S. 557, 562-63 (1980).

32. See, e.g., Erznoznik v. Jacksonville, 422 U.S. 205, 209 (1975) (recognizing the validity of restrictions in offensive speech when the degree of captivity makes it impractical to avoid exposure); Cohen v. California, 403 U.S. 15, 21 (1971) (finding that persons could avoid offensive word printed on another's jacket by simply averting their eyes).

33. See, e.g., Hazelwood School Dist. v. Kuhlmeier, 484 U.S. 260, 260 (1988) (holding that deletion of a pregnancy article from a high school newspaper did not violate the students' First Amendment rights); Bethel School Dist. No. 403 v. Fraser, 478 U.S. 675, 675 (1986) (involving a public school teacher that referred to a student government candidate "in terms of an elaborate, graphic, and explicit sexual metaphor" during a speech to approximately 600 students).

34. See Virginia v. Black, 538 U.S. 343, 343 (2003) (holding that a state "may ban cross burning carried out with the intent to intimidate").

35. Examples of expressive conduct not given full constitutional protection include nude dancing, Barnes v. Glen Theatre, Inc., 501 U.S. 560, 566-67 (1991), sleeping in national parks, that do not allowing "camping," to protest the plight of the homeless, Clark v. Cmty. for Creative NonViolence, 468 U.S. 288, 293-96 (1984), and burning a military draft card to protest a war, United States v. O'Brien, 391 U.S. 367, 376-77 (1968).

36. See Frisby v. Schultz, 487 U.S. 474, 486 (1988) (targeted picketing does "not seek to disseminate a message to the general public, but to intrude upon the targeted resident, and to do so in an especially offensive way"); $i d$. at 498 (Stevens, J., dissenting) ("Picketing is a form of speech that, by virtue of its repetition of message and often hostile presentation, may be disruptive of an environment irrespective of the substantive message conveyed."); City of San Jose v. Superior Court, 38 Cal. Rptr. 2d 205, 209 (Ct. App. 1995) ("In short, the United States Supreme Court has described targeted picketing as highly offensive conduct which is not entitled to the same level of First Amendment protection as is more general expression of political or social views."). 
In Frisby v. Schultz, the Supreme Court upheld a municipal ordinance that banned targeted picketing "before or about" a particular residence. $^{37}$ Careful examination of the majority opinion in Frisby, however, provides only limited guidance in assessing the new funeral picketing laws. The Frisby majority made several points of importance: (1) public streets and sidewalks are quintessential public fora, irrespective of their location or nature; ${ }^{38}$ (2) "[t] he State's interest in protecting the ... privacy of the home is certainly of the highest order" 39 and the home is "unique"; 40 and (3) targeted picketing may receive less constitutional protection than other forms of speech, at least when it is "directed at the household, not the public," [and unwilling] audience. ${ }^{42}$

Important to the Court's decision in Frisby were the facts that the home is "unique" in society's expectations of privacy and that other forms of speech, such as marching down residential streets and sidewalks, door-to-door solicitation, and even leafleting, remained available. ${ }^{43}$ The Frisby majority concluded that the State's interests were substantial, that the ordinance was narrowly tailored, and that the ordinance left open ample alternative channels of communication. ${ }^{44}$ In Madsen v. Women's Health Center, Inc., ${ }^{45}$ however, the Court rejected a court-ordered injunction that banned residential picketing within 300 feet of the homes of persons employed by medical clinics performing abortions. ${ }^{46}$ In potential contrast to Frisby, the Court found the 300-foot buffer zone around clinic employee residences too broad to be constitutional. ${ }^{47}$

37. 487 U.S. at $474,488$.

38. See id. at 480-81 ("'Wherever the title of streets and parks may rest, they have immemorially been held in trust for the use of the public."') (quoting Hague v. CIO, 307 U.S. 496, 515 (1939)); id. at 481 ("No particularized inquiry into the precise nature of a specific street is necessary; all public streets are held in the public trust and are properly considered traditional public fora."). This conclusion subjects the regulation of speech on public streets and sidewalks to the more rigorous time, place, and manner analysis.

39. Id. at 484 (quoting Carey v. Brown, 447 U.S. 455, 471 (1980)).

40. Id. (citing Gregory v. Chicago, 394 U.S. 111, 125 (1969) (Black, J., concurring)).

41. Id. at 486 .

42. Id. at 487 .

43. Id. at $483-84$.

44. Id. at $484-88$.

45. 512 U.S. 753 (1994). The injunction also imposed a thirty-six-foot buffer zone around such clinics, for purposes of restricting noise, protecting ingress and egress, and banning observable images on signs and posters. Id. at 768-69.

46. Id. at 774-75.

47. Id. 
Perhaps importantly, the Court distinguished between the time, place, and manner analysis it would apply to ordinances or statutes regulating public fora and its review in Madsen of court-imposed injunctive restrictions on public fora. ${ }^{48}$ The Court applied a higher standard in Madsen - requiring that court-imposed restrictions burden no more speech than necessary to serve a significant government interest, a standard the Court itself described as "somewhat more stringent" than the time, place, and manner standard for evaluating restrictions on public fora. $^{49}$

Applying the heightened standard, the Court concluded that the ban on picketing within 300 feet of clinic employees' residences was too broad. ${ }^{50}$ In so doing, the Court distinguished Frisby, pointing out that the ordinance in that case created a much smaller buffer zone and did not preclude marching around the block or other such activities; it only precluded focused picketing targeted at a single residence. ${ }^{51}$

In any event, what is clear from both Frisby and Madsen is that targeted picketing - though perhaps a less-favored form of speech-will receive significant First Amendment protection. It is not open to government simply to ban targeted picketing without concern for any potential First Amendment violations. Rather, laws restricting picketing in traditional public fora will receive significant scrutiny under the First Amendment, and at a minimum they likely will have to satisfy the time, place, and manner test for such regulations discussed below.

\section{Captive Audiences}

Another argument that can and has been made to support funeral picketing laws is that the protesters are targeting a "captive audience" and therefore are subject to greater regulation than might otherwise be the case. In other words, the argument is that the mourners at a funeral cannot really escape protesters and messages located just outside a church or cemetery. In this respect, the argument is much like the Frisby

48. Id. at 764-65. Indeed, whether courts can or should apply the same or similar standards to both injunctions and legislation that restrict free expression are issues of complexity, on which there are likely to be differences of opinion. See Christina E. Wells, Bringing Structure to the Law of Injunctions Against Expression, 51 CASE W. RES. L. REV. 1, 1-5 (2000) (arguing that the standards necessarily must be different and that the Supreme Court has failed to articulate a comprehensive and sensible approach to evaluating injunctions which restrict expression).

49. Madsen, 512 U.S. at 765.

50. Id. at $774-75$.

51. Id. 
rationale that people in their homes cannot avoid targeted picketing directly outside, and therefore such conduct may be banned or limited.

The captive audience idea indeed finds its source in the idea of protecting people within their homes. In Rowan v. United States Post Office Department, ${ }^{52}$ the Court upheld a statute permitting individualsassisted by the United States Postal Service - to preclude the delivery to their homes of some offensive mail. ${ }^{53}$ Indeed, the Court recognized that perhaps uniquely in the home, people should have the right "to be free from sights, sounds, and tangible matter we do not want." ${ }^{, 54}$

But the Court also has been notoriously reluctant to apply the captive audience rationale outside the home. A famous example is Cohen $v$. California, ${ }^{55}$ in which a man was arrested for disorderly conduct for wearing a jacket with the inscription "Fuck the Draft" in a Los Angeles courthouse. ${ }^{56}$ Obviously, the use of profanity as a means of expression cannot be banned generally, but the Supreme Court observed that people do have some right not to be forced to confront unwelcome messages in at least some circumstances, particularly in the home. ${ }^{57}$ That said, the Court in Cohen clearly was reluctant to apply a captive audience rationale to justify suppression of speech other than to protect privacy in the home. Thus, the Court indicated that, outside the home, the captive audience justification for regulating speech might stand up only when "substantial privacy interests are being invaded in an essentially intolerable manner." 58

How the captive audience concept might apply to funeral picketing is not readily apparent. The first question would be whether there are substantial privacy interests at stake for mourners at funerals and memorial services. The second is whether the picketers' conduct invades such privacy interests in an "essentially intolerable manner."

There is little instructive case law, but on the question of whether there are substantial privacy interests at stake, the Supreme Court in a different context observed that "[f]amily members have a personal stake in honoring and mourning their dead and objecting to unwarranted public exploitation that, by intruding upon their own grief, tends to degrade the rites and respect they seek to accord to the deceased person who was

52. 397 U.S. 728 (1970).

53. Id. at 738 .

54. Id. at 736 .

55. 403 U.S. 15 (1971).

56. Id. at 16

57. Id. at 21 .

58. Id. 
once their own." 59 For most people, protecting privacy at funerals and memorial services likely would seem to be a strong governmental interest, maybe even close to as strong as the interest in protecting the privacy of our homes. $^{60}$

Indeed, the Supreme Court has explained that the "recognizable privacy interest in avoiding unwanted communications varies widely in different settings. It is far less important when 'strolling through Central Park' than when 'in the confines of one's own home,' or when persons are "powerless to avoid' it." 11 Moreover, the Court has opined that "[s]tates and municipalities plainly have a substantial interest in controlling the activity around certain public and private places. For example, we have recognized the special governmental interests surrounding schools, courthouses, polling places, and private homes." ${ }^{\prime 2}$ Thus, it is certainly both reasonable and justifiable under the Supreme Court's precedents to conclude that there is a substantial privacy interest at stake in the context of funerals and memorial services.

Perhaps the more difficult question is whether the funeral picketers' conduct interferes with that privacy in an essentially intolerable manner. Answering that question may in fact require careful consideration of the precise conduct in which protesters are engaged. For instance, it seems an easy matter to conclude that making noise with the intent to intrude upon a funeral would be acting in an essentially intolerable manner, and there seems to be consensus that the funeral picketing acts are constitutional insofar as they bar such noise.

Standing silently with a sign along a road leading to a cemetery, however, is a more difficult situation to evaluate. Is it intolerable to display messages to which mourners may object anywhere on the route to, or in sight of, the location of a funeral service? Maybe. And does it matter that the message is being conveyed from a traditional public forum, such as a public sidewalk open generally for expressive activity? Maybe.

59. Nat'l Archives \& Records Admin. v. Favish, 541 U.S. 157, 168 (2004).

60. One commentator, addressing antiabortion protests outside churches, opined that " $\mathrm{i}] \mathrm{f}$ the current Supreme Court were to expand the captive audience doctrine beyond the four walls of the home, churches present one of the strongest cases." Alan Phelps, Note, Picketing and Prayer: Restricting Freedom of Expression Outside Churches, 85 CORNELl L. ReV. 271, 300 (1999). Whether or not the courts would agree with that assertion, the captive audience problem and the government's interest in protecting the privacy and dignity of funerals would appear to be even stronger than in the context of attending religious worship services generally.

61. Hill v. Colorado, 530 U.S. 703, 716 (2000) (quoting Cohen, 403 U.S. at 21-22).

62. Id. at 728 (internal footnotes and citations omitted). 
Ultimately, the captive audience concept may provide one of the best rationales in support of funeral picketing laws, but it is not apparent that adopting such an approach necessarily would resolve the laws' constitutionality. Nor has the Supreme Court ever applied the doctrine to actually uphold the constitutionality of any restriction on unwanted speech anywhere other than in the home. Funerals and memorial services often take place in or near public places.

Extracting principles from Frisby regarding the lesser status of targeted picketing as a form of protected speech and the strong interest in protecting privacy in the home, and combining those with the recognized potential for captive audiences and the likely recognition that ensuring privacy at funerals is a substantial governmental interest, a very reasonable argument can be made that some restrictions on funeral picketing are constitutional. What remains unclear is the extent of those restrictions - including whether buffer zones are appropriate and, if so, of what distance? It seems relatively clear that noise which intrudes on services can be banned as disorderly conduct, but as the next subpart briefly discusses, it seems very unlikely that disorderly conduct constitutionally can be defined to include simply the quiet display of offensive messages. Thus, of the suggested rationales for restricting funeral picketing as a lesser form of speech, the best and strongest one may be the captive audience concept.

\section{Fighting Words}

Another argument sometimes made in support of funeral picketing laws is that they only restrict fighting words, a category of speech that is not constitutionally protected. The fighting-words doctrine originated in Chaplinsky v. New Hampshire, ${ }^{63}$ a case in which the Supreme Court upheld a defendant's conviction for breach of the peace for calling a public officer "“a God damned racketeer' and 'a damned Fascist.",64 The Court's rationale was that some words "by their very utterance inflict injury or tend to incite an immediate breach of the peace" and thus "are no essential part of any exposition of ideas. $" 65$

In the funeral picketing context, the argument is that the Westboro Baptist Church's messages often, if not always, fit the definition of fighting words. Certainly, at least some of their messages may meet the

\footnotetext{
63. 315 U.S. 568 (1942).

64. Id. at 569 .

65. Id. at 572 (citation omitted).
} 
definition, and their goal certainly is to be provocative. But the problem with relying on the fighting-words doctrine is that the Supreme Court has never upheld a conviction on that basis since Chaplinsky. Instead, the Court has effectively discarded the doctrine, construing it narrowly whenever the occasion to address it has arisen. For instance, in Texas $v$. Johnson, ${ }^{66}$ the Court expressly rejected the notion that burning an American flag as a way to communicate a message constitutes fighting words. ${ }^{67}$

The closest the Court has come to justifying a law on the basis of fighting words since Chaplinsky is perhaps Virginia v. Black, ${ }^{68}$ a case in which the Court held it would be constitutional for a state to criminalize burning a cross with intent to intimidate. ${ }^{69}$ But in reaching that conclusion, the Court relied both on the fact that such a statute essentially would be criminalizing an actual threat of violence and on the long history of cross burning being used (primarily by the Ku Klux Klan) to intimidate African-Americans. ${ }^{70}$ So, in actuality, the Court did not rely on Chaplinsky or the fighting-words doctrine but, rather, on the idea of a "true threat." 71 The funeral picketers are not engaging in activity that either presents an actual threat of violence (they are, in fact, completely nonviolent and refuse even to engage in civil disobedience) or that reflects a historical understanding of an implied or actual threat of violence.

Furthermore, relying on a legal doctrine that would permit audience reaction to determine whether speech is protected or not seems unwise for obvious reasons, and this perhaps explains why the Supreme Court has effectively abandoned the fighting-words doctrine. The First Amendment simply does not track notions of civility and decency in determining what speech is protected, nor would most Americans probably want it to do so. Thus, the fighting-words doctrine has proven unworkable as a method for analyzing restrictions on speech, and likely will not justify the funeral picketing laws. The better rationale is

66. 491 U.S. 397 (1989).

67. Id. at 409 .

68. 538 U.S. 343 (2003).

69. Id. at 347 .

70. See id. at 363 ("The First Amendment permits Virginia to outlaw cross burnings done with the intent to intimidate because burning a cross is a particularly virulent form of intimidation. Instead of prohibiting all intimidating messages, Virginia may choose to regulate this subset of intimidating messages in light of cross burning's long and pernicious history as a signal of impending violence.").

71. Id. at $359-60$ 
probably a combination of the captive audience and targeted picketing principles discussed above.

\section{B. Are Funeral Picketing Laws Content and Viewpoint Neutral?}

\section{In General}

An important First Amendment free speech question is whether the funeral picketing acts are content and viewpoint neutral. ${ }^{72}$ If the laws effectively prohibit speech either on a particular topic or on a particular side of a debated issue, then they almost certainly will be held unconstitutional. Content-based laws can be justified only by demonstrating a compelling governmental interest and narrow tailoring to serve such an interest, and it is doubtful that the funeral picketing laws could meet either requirement.

If a law regulates speech on the basis of content, it is far more likely to be found unconstitutional, irrespective of the time, place, and manner regulation doctrine discussed below. ${ }^{73}$ As the Court has stated, "[s]elective exclusions from a public forum may not be based on content alone, and may not be justified by reference to content alone."74 Even in the context of a nonpublic forum, regulation must not be "an effort to suppress expression merely because public officials oppose the speaker's view." 75

Importantly, though the legislative motive behind funeral picketing laws is clear, and though the activities of the Westboro Baptist Church members are the clear cause for such laws, the constitutional issue is whether the laws on their faces target either content or viewpoint. In general, this seems an easy question to answer.

72. See, e.g., CHEMERINSKY, supra note 3, § 11.21, at 932-41 (discussing Supreme Court's approach to content-based and content-neutral cases); DANIEL A. FARBER, THE FIRST AMENDMENT 21-33 (2d ed. 2003) (discussing the Supreme Court's application of the content distinction); NOWAK \& ROTUNDA, supra note $3, \S 16.1$, at 590-96 (discussing validity of content-based, viewpoint-based, and content-neutral laws).

73. A recently published empirical survey of the Supreme Court's First Amendment cases confirms this point. Barry P. McDonald, Speech and Distrust: Rethinking the Content Approach to Protecting the Freedom of Expression, 81 NOTRE DAME L. REV. 1347, 1351-52 (2006). Indeed, in the cases scrutinized, Professor McDonald found that invariably regulations were invalidated if the Court concluded they were content-based, while virtually all regulations the Court determined were content-neutral were upheld. Id. For more on the doctrine of content neutrality and its origins in First Amendment jurisprudence, see generally William E. Lee, Modernizing the Law of Open-Air Speech: The Hughes Court and the Birth of Content-Neutral Balancing, 13 WM. \& MARY BILL RTS. J. 1219 (2005).

74. Police Dep't of Chi. v. Mosley, 408 U.S. 92, 96 (1972).

75. Perry Educ. Ass'n v. Perry Local Educators' Ass’n, 460 U.S. 37, 46 (1983). 
By using terms like "picketing," "protest activities," and other such generic phrases, none of the current laws seem likely to run afoul of either content or viewpoint neutrality requirements on their face. Rather, they apply to specified activities (like picketing) irrespective of the message being conveyed. Thus, as a general matter, the funeral picketing laws appear to be both content and viewpoint neutral on their faces.

What is perhaps more problematic, however, is whether such laws may be applied and enforced in violation of content or viewpoint neutrality principles, particularly if pickets, signs, or speech conveying different messages than those of the Westboro Baptist Church are permitted within the buffer zones. For instance, reading the laws to permit signs supporting the war in Iraq, or thanking our troops who serve in Iraq, likely would be viewed as viewpoint discrimination. Likewise, permitting the loud noise of motorcycle engines being revved within the buffer zone, while prohibiting the singing of songs or chanting of slogans across the street by the Westboro Baptist Church members, might be viewed as viewpoint discrimination or uneven enforcement of the laws.

\section{Vagueness and Overbreadth}

Other potentially serious issues concerning the funeral picketing laws include whether they are vague or overly broad. Many of the funeral picketing acts apply to "disorderly conduct," but define that term in ways that make it far from clear what conduct is covered. This is a classic First Amendment "vagueness" problem if, in fact, such broad definitions include protected expressive activity.

The Supreme Court long has required that laws potentially infringing on protected speech be reasonably clear in terms of their scope and application. ${ }^{76}$ Thus, courts evaluating laws that regulate or affect speech sometimes strike them down on vagueness grounds, or else adopt a "limiting" construction in order to save such laws.

Some of the funeral picketing laws are quite clear about the activities covered (e.g., picketing or making noise that intrudes on a funeral service $)^{77}$ but others are less clear, using more open-ended notions such

\footnotetext{
76. See, e.g., CHEMERINSKY, supra note $3, \S 11.2 .2$, at $941-43$ (discussing vagueness doctrine); FARBER, supra note 72, at 49-53 (discussing vagueness and overbreadth doctrines and "saving construction"); NOWAK \& ROTUNDA, supra note 3, § 16.3, at 607-08 (discussing rationales for vagueness doctrine).

77. E.g., Del. Code ANN. tit. 11, 1303 (Westlaw through 76 Laws 2007, ch. 3).
} 
as any activity that "tends to disrupt" a funeral service. ${ }^{78}$ From a vagueness perspective, it is not clear, for instance, whether such prohibitions apply to the silent holding of a picket that contains a message offensive to mourners.

Furthermore, under the Supreme Court's "overbreadth" doctrine, a law may be stricken even when it legitimately regulates some expressive activity if at the same time it reaches a substantial amount of protected speech activity. ${ }^{79}$ The point is to encourage government to regulate narrowly and precisely, so as not to include or discourage protected speech. In the Supreme Court's judgment, it is better to strike a law or judicially narrow it than to let an overly expansive law remain in place. This reflects, in part, the high value that the Court has placed on free speech. But, as under the vagueness doctrine, one way for courts to cure overbreadth is simply to give the law a narrowing construction, so that it does not include protected speech.

Thus, even if a court is inclined to uphold a particular funeral picketing act against constitutional challenge, it may need to adopt a limiting construction of such a law, both to make the law's reach clear (avoiding the vagueness problem), and to minimize or eliminate the law's effect on protected speech (solving the overbreadth problem). Although a vague law may be applied in an overly broad fashion, or an overly broad law may also be vague, in fact vagueness and overbreadth are distinct - though sometimes overlapping - concerns. ${ }^{80}$

\section{Are Funeral Picketing Laws Valid Time, Place, and Manner Regulations?}

Recognizing that speech on government property often presents competing values, the Supreme Court has developed the time, place, and manner doctrine for evaluating government restrictions on speech in such situations. ${ }^{81}$ The doctrine creates three categories of "fora" for purposes of establishing the constitutional standards by which to measure regulation of speech. ${ }^{82}$ The time, place, and manner doctrine in fact is

78. E.g., Fla. STAT. $\S \S 871.01-.02$ (West, Westlaw through ch. 1 of 2007 Spec. 'A' Sess.).

79. CHEMERINSKY, supra note $3, \S 11.2 .2$, at 943-48; FARBER, supra note 72, at 21-33; NOWAK \& ROTUNDA, supra note $3, \S 16.2$, at 606-07.

80. CHEMERINSKY, supra note $3, \S 11.2 .2$, at 948-49.

81. Id. $\S 11.4 .2$, at 1124-44; NowAK \& RoTUNDA, supra note 3, § 16.26, at 699-701; see also FARBER, supra note 72, at 171-89 (describing the development of the public forum doctrine and different methods of regulations and types of forums).

82. See Perry Educ. Ass'n v. Perry Local Educators' Ass'n, 460 U.S. 37, 45-49 (1983). 
likely to be the determinative constitutional analysis applied to funeral picketing acts. ${ }^{83}$

Assuming that the protesters' speech is protected ${ }^{84}$ and given that the protesters are claiming a right to speak only on publicly owned property such as streets and sidewalks, the funeral picketing laws ultimately will stand or fall based on the courts' application of this important First Amendment doctrine. Thus, a critical step in the First Amendment analysis of funeral picketing acts is to determine the nature of the "forum" being regulated and the resulting constitutional standards that apply to such fora.

1. The Time, Place, and Manner Regulation Doctrine

a. Traditional Public Fora

A "traditional public forum" is one that, since time immemorial, has been open to and used for speech and expression. Typical examples are town squares, public parks, public streets, and public sidewalks. It is not sufficient that government owns the property - rather, the test is whether the property is of a type that has traditionally been used as a forum for expression.

In a traditional public forum, government cannot close the forum to all speech, nor regulate on the basis of content without a compelling state interest. Content-neutral time, place, and manner regulations, however, may be imposed if they (1) serve a significant government interest, (2) are narrowly tailored, and (3) leave open ample alternative channels of

83. For purposes of this Article, the author assumes the courts will apply traditional First Amendment doctrines, such as the time, place, and manner doctrine as articulated below. Thus, in this respect, the Article is positive rather than normative in its approach to the First Amendment issues that funeral picketing acts raise.

That said, there are of course many alternative ways courts could approach First Amendment free speech jurisprudence in this context. For a particularly interesting and recent example of such a proposal, see Timothy Zick, Speech and Spatial Tactics, 84 TEX. L. REV. 581, 581-91 (2006), which gives several striking examples of recent, severe restrictions on political speech in public places, and argues for more rigorous judicial review of such restrictions because current doctrine gives inadequate weight to the important connection between speech and location. See also James J. Knicely \& John W. Whitehead, The Caging of Free Speech in America, 14 TEMP. POL. \& CIV. RTS. L. REV. 455, 472-90 (2005) (discussing the restrictions on protesters at the 2004 Democratic National Convention in Boston and arguing that current First Amendment doctrine should be adjusted to subject such restrictions to a "necessity" requirement, require that alternative avenues of communication be tied to the protesters' intended audience, and put the burden of justifying restrictions and fashioning appropriate relief on the government).

84. In other words, the protesters' speech is not deprived of all protection as targeting picketing, fighting words, or occurring before a captive audience. See supra Part III.A. 
communication. Thus, even though public streets and sidewalks generally are traditional public fora, government retains the ability to impose content-neutral time, place, and manner regulations in such locations, subject to the standards stated in the preceding sentence.

\section{b. Limited Public Fora}

A "limited public forum" is a public area that has not necessarily been open for expression as a matter of tradition and history, but which government has opened or designated for such purposes. Again, it is not sufficient that the government owns the property; rather, the property must be designated for use for expressive purposes. ${ }^{85}$ Examples in the case law include a public school or public university building which nonschool groups are allowed to use for nonschool functions ${ }^{86}$ and a state fairgrounds. ${ }^{87}$

In limited public fora, the same rules apply as in a traditional public forum, except that government retains the option of closing the forum entirely, rather than adopting valid time, place, and manner regulations.

\section{c. Nonpublic Fora}

The third category is a "nonpublic forum." A nonpublic forum is one that has not by tradition or by designation been open for public communication. Government is given considerably more leeway in the regulation of a nonpublic forum, with restrictions generally upheld if they are "reasonable" in light of the purpose(s) which the forum serves and so long as any regulation is not an effort to suppress speech which government opposes.

An example of a nonpublic forum is a cemetery. ${ }^{88}$ Another example in the cases is churches-by definition since they generally are not publicly owned. ${ }^{89}$ Thus, cemeteries and churches - the locations where

85. See, e.g., Preminger v. Principi, 422 F.3d 815, 824 (9th Cir. 2005) ("Designated public fora are not created haphazardly, and the Supreme Court has found them to exist only in places where the government has expressly dedicated the property for expressive conduct.").

86. Lamb's Chapel v. Ctr. Moriches Union Free Sch. Dist., 508 U.S. 384, 391-97 (1993); Widmar v. Vincent, 454 U.S. 263, 267-70 (1981).

87. Heffron v. Int'l Soc'y for Krishna Consciousness, Inc., 452 U.S. 640, 648-55 (1981).

88. See Lower v. Bd. of Dirs. of Haskell County Cemetery Dist., 56 P.3d 235, 244 (Kan. 2002) ("[W]hile a cemetery may be open and accessible to the public, cemeteries may properly be classified as nonpublic fora for purposes of constitutional review."); see also Warner v. City of Boca Raton, 420 F.3d 1308, 1310 n.1 (11th Cir. 2005) ("We reject Plaintiffs' arguments that cemeteries are public fora. We are aware of no federal court that has concluded otherwise.").

89. See, e.g., City of Prairie Village v. Hogan, 855 P.2d 949, 952-54 (Kan. 1993) (construing 
funerals and memorial services perhaps are most frequently held - either are not subject to time, place, and manner analysis at all, because they are privately owned, or at most they are nonpublic fora where government has considerable leeway to prohibit or restrict expressive activities.

2. Funeral Picketing Acts as Time, Place, and Manner Regulations

The first question is what fora funeral picketing acts are regulating. To the extent they regulate nonpublic fora, their constitutionality is on much firmer ground.

The funeral picketing acts, however, clearly restrict expressive activity not just within or on the premises of a cemetery or church, but also on traditional public fora such as adjacent public streets and sidewalks. Any regulation that restricts speech in such traditional public fora has to satisfy the three standards of Part III.C.1.a., above.

The argument could be made that funeral picketing acts satisfy those requirements as follows: (1) they serve the significant government interest in preserving and protecting the sanctity and dignity of religious or nonreligious memorial and funeral services, as well as protecting the privacy of family and friends of the deceased during a time of mourning and distress; (2) they are narrowly tailored because they limit targeted picketing only for a relatively brief time period and only within a certain distance of a funeral; and (3) they leave open ample alternative channels of communication because targeted picketing is permitted at all other times and even during a funeral at a certain distance.

But there are, of course, counterarguments. First, though the government may have a significant interest in protecting the dignity of funerals and the privacy of mourners, it is serving that interest by admittedly limiting others' constitutionally protected right to free speech. Second, the laws are not narrowly tailored because they ban or limit the protected speech at the only times and in the only places where it matters, the context in which the messages are most likely to have an

city ordinance that banned picketing of residences or churches to prohibit only focused picketing in front of a residence or church, but declining to determine the ordinance's constitutionality because the defendant's conduct did not violate the ordinance as construed); St. David's Episcopal Church v. Westboro Baptist Church, Inc., 921 P.2d 821, 830 (Kan. Ct. App. 1996) ("We agree with the trial court and find that, in addition to the government interest in protecting residential and clinical privacy, the government has a legitimate interest in protecting the privacy of one's place of worship as well."). But see Olmer v. City of Lincoln, 192 F.3d 1176, 1181-82 (8th Cir. 1999) (rejecting, by a two-to-one vote, the argument that churches should receive the same level of protection from picketing and protests as the private residences of individuals). 
effect - when and where the intended audience is present. Thus, the laws effectively are complete bans on protected speech during a funeral, at least within the buffer zones. Third, as the second argument suggests, although there undoubtedly are alternative avenues of communication open during a funeral, it is arguable that such avenues (out of sight of the funerals, for example) are not constitutionally sufficient.

So, how might a court evaluate these competing claims? Of the two common components of funeral picketing buffer zone restrictions-the time period during which the limit applies and the distance requirement - the time period does not in and of itself appear to be of as much potential constitutional concern as the distance requirement. In other words, the time period may not really matter if the distance limits are relatively small. But large distance limits themselves are problematic, irrespective of the time during which they apply.

In fact, relatively few court decisions have addressed the constitutionality of buffer zones that restrict speech in traditional public fora, and none have done so in this context. ${ }^{90}$ Even in the abortion protest cases the Supreme Court has not upheld a buffer zone greater than thirty-six feet around medical clinic entrances and driveways. And it is inescapable that any sizeable buffer zone around public or quasipublic areas such as cemeteries or churches located in urban areas is likely to include traditional public fora such as public sidewalks and streets.

90. There are some decisions, though none by the Supreme Court, addressing the use of what are sometimes called "free speech" or "demonstration" zones. For some events, such as an appearance by the President of the United States or a national convention of one of the major political parties, all protesters are limited to certain locations (sometimes literally by fencing or caging them in), apparently for security reasons and to ensure that the events are orderly. See, e.g., James Bovard, Free-Speech Zone: The Administration Quarantines Dissent, AM. Conservative, Dec. 15, 2003, at 12, 12 ("When President Bush travels around the United States, the Secret Service visits the location ahead of time and orders local police to set up 'free speech zones' or 'protest zones' where people opposed to Bush policies (and sometimes sign carrying supporters) are quarantined."); Michael J. Hampson, Protesting the President: Free Speech Zones and the First Amendment, 58 RUTGERS L. REV. 245, 245-46 (2005) (discussing the Secret Service's practice of placing political protestors critical of the President in "free speech zones" removed from the sight of the President and news media while allowing supportive members of the public to remain close); Zick, supra note 83, at 581-82 (listing examples). Generally, such zones have been upheld as constitutional restrictions on the location of speech, or else have not been subject to effective challenge in court due to timing and other factors. See, e.g., Citizens For Peace In Space v. City of Colorado Springs, 477 F.3d 1212, 1217-26 (10th Cir. 2007) (upholding imposition of a "limited access area"/"security zone" that extended for several blocks in all directions around the Broadmoor Hotel during a conference of the defense ministers of NATO countries). But even assuming arguendo that security concerns and orderliness justify such limitations on protest activities, the funeral picketers appear to raise neither concern. There has never been any suggestion that the members of the Westboro Baptist Church are an actual threat to anyone, nor do they appear to block streets or generally impede access to any of the events they picket. 
Thus, the real test for funeral picketing laws is the constitutionality of restricting speech on public sidewalks and streets - traditional public fora-near funerals and memorial services. There is no question that such activities can be prohibited on private property under traditional trespass laws, and no question that government can prohibit such activities on government property which is a nonpublic forum. Accordingly, this Article analyzes the funeral picketing laws as they affect traditional public fora, and all of them do, focusing on the constitutionality of the buffer zone distance requirements and the disorderly conduct prohibitions.

\section{a. Buffer Zones}

The most common feature of the recently enacted or proposed funeral picketing laws is to limit protesters to an area a certain minimum distance away from funerals, memorial services, churches, cemeteries, and so forth. The laws are phrased in various ways, sometimes measuring the distance from the "service" or sometimes from the "entrance" to one of the locations listed. And usually, the buffer zone is in effect from thirty minutes to an hour before a service until thirty minutes to two hours after a service. Only a few laws have no specified buffer zone, including Missouri's original enactment which simply prohibits protesting "in front of or about" a funeral, language that was challenged in court and drawn into question by prior litigation in Kansas.

The buffer zones in the laws range from as short as 100 feet to as far as 1000 feet. About fifteen states impose a 500-foot buffer zone, and eleven impose 300-foot zones. Only four impose a 1000 -foot buffer, with the remainder imposing zones shorter than 300 feet or no foot limit at all.

No Supreme Court decisions directly address restrictions on picketing at public locations within a certain distance of a church, cemetery, or funeral during a specific time period, and there is very little case law from any jurisdiction. In Madsen v. Women's Health Center, Inc. ${ }^{91}$ the Court rejected a lower court injunction that banned residential picketing within 300 feet of the homes of persons employed by medical clinics performing abortions, finding it too broadly applicable and too large to be constitutional. ${ }^{92}$ The Court in Madsen reiterated, however,

91. 512 U.S. 753 (1994).

92. Id. at 775 . 
that Frisby v. Schultz recognizes government may ban targeted picketing in front of a particular home. ${ }^{93}$

The injunction at issue in Madsen also imposed a thirty-six-foot buffer zone around such clinics, for purposes of restricting noise, protecting ingress and egress, and banning observable images on signs and posters. The Court upheld the thirty-six-foot buffer zone for noise restrictions and providing access to the clinics, but struck it down with respect to banning observable images on all property surrounding the clinic, when access was not impaired. ${ }^{94}$

Another Supreme Court buffer zone case is Hill v. Colorado, ${ }^{95}$ in which the Court considered the constitutionality of a Colorado statute that, among other things, prohibited persons from approaching within 8 feet of patients who were within 100 feet of medical clinics, when the purposes of those so approaching were to engage the patients in conversation, "counsel" them, display messages, hand out leaflets, and so forth. ${ }^{96}$ The Court upheld the "floating buffer zone" as a legitimate time, place, and manner regulation in the context in which it applied. ${ }^{97}$ According to the Court, the floating buffer zone served significant governmental interests, was narrowly tailored, and left open ample alternative channels of communication. Further, the Supreme Court concluded that the law was neither unconstitutionally overbroad nor vague. $^{98}$

At least a couple of questions arise from these cases. First, will courts view the funeral context as similar to the home? A stronger case for protection from offensive protesters? Or a weaker case? Second, even assuming that targeted picketing of funerals is treated legally as similar to such picketing of individual residences, what size buffer zone can withstand constitutional scrutiny?

As for the first question, courts may well find the privacy interests in the funeral context to be atypically strong, just as the Court found the interest in privacy of the home in Frisby. In a different context, the Supreme Court certainly has suggested as much: "Family members have a personal stake in honoring and mourning their dead and objecting to

93. Id.

94. Id. at 769-73. In Schenck v. Pro-Choice Network of Western New York, 519 U.S. 357, 377-85 (1997), the Court, applying Madsen, upheld a 15-foot "fixed" buffer zone around medical clinic entrances and driveways, but struck down a 15-foot "floating" buffer zone that applied to vehicles and patients entering or leaving a clinic.

95. 530 U.S. 703 (2000).

96. Id. at $707 \mathrm{n} .1$.

97. Id. at 725-30.

98. Id. at 730-33. 
unwarranted public exploitation that, by intruding on their own grief, tends to degrade the rites and respect they seek to accord to the deceased person who was once their own." 99 Moreover, focused or targeted picketing in a nonpublic forum, such as a cemetery, church, or mortuary, is subject to greater regulation than picketing in a traditional public forum, such as a public sidewalk or street. It seems likely that targeted picketing of funerals can be banned in nonpublic fora.

That said, there are some serious constitutional issues with funeral picketing acts. Such laws in general rely on a buffer-zone approach about which the Supreme Court has always seemed skeptical. ${ }^{100}$ Buffer zones of 300 feet and greater - in which targeted picketing is banned-at a minimum appear suspect in light of Frisby and Madsen. ${ }^{101}$

These cases suggest that a buffer zone may be permissible for purposes such as limiting noise and ensuring ingress and egress, but not simply to prevent persons from seeing messages or images that they may find disturbing or offensive. Further, the cases suggest that the Supreme Court may uphold fairly small buffer zones, but even very small buffers must be narrowly tailored to further the permissible purposes. Thus, buffer zones of 300 feet or greater, and which draw a circle completely around a specified location, seem at least constitutionally suspect under Frisby, Madsen, and Hill.

\section{b. Disorderly Conduct: Noise and Disruption Prohibitions}

Another common feature of funeral picketing acts - though less universal than the adoption of buffer zones - is the prohibition of conduct that is loud, noisy, disorderly, or otherwise disrupts a funeral or memorial service. This aspect of such laws is probably on stronger constitutional ground, though much depends on the definition of the conduct that is prohibited. Certainly, it is constitutional to prohibit conduct that is unreasonably loud, violent, or physically disrupts funeral

99. Nat'l Archives \& Records Admin. v. Favish, 541 U.S. 157, 168 (2004).

100. Indeed, one requirement for upholding a time, place, and manner regulation in a traditional public forum is that it leaves open ample alternative avenues of communication. But the Supreme Court long has held that "one is not to have the exercise of his liberty of expression in appropriate places abridged on the plea that it may be exercised in some other place." Schneider v. State, 308 U.S. 147, 163 (1939).

101. A state trial judge entered an injunction restraining the Westboro Baptist Church protesters from approaching within 215 feet from the entrance of a church in Topeka, but the Kansas appellate courts never actually determined the injunction's constitutionality. See St. David's Episcopal Church v. Westboro Baptist Church, Inc., 921 P.2d 821, 831-33 (1996) (concluding that the court lacked sufficient information to evaluate the 215 -foot buffer zone and expressly declining to decide "whether a court can enjoin picketing outside of a church on public sidewalks"). 
services. But if "disorderly" simply means displaying messages that "mourners do not want to see," then such prohibitions likely are unconstitutional.

About two-thirds of the state laws or proposals include language along these lines, prohibiting either noise, disruption, disorderly conduct, threats, or fighting words. The phrasing of the laws in this respect varies considerably. Some laws require that the speaker act with the intent to disrupt the services, while others do not. The Supreme Court long has recognized that some speech activities which result in noise may be inconsistent with the primary use of some public property, a rule that would apply strongly with respect to noise created during a funeral or memorial service. ${ }^{102}$

Speech cannot be prohibited solely because a traditional public forum is adjacent to property that is not a public forum. The Supreme Court, in addressing the sidewalks surrounding its own building, stated as follows: "Traditional public forum property occupies a special position in terms of First Amendment protection and will not lose its historically recognized character for the reason that it abuts government property that has been dedicated to use other than as a forum for public expression."103

Thus, prohibiting purposeful disruption of funeral and memorial services by use of noise or physical interference is constitutional, but it must be done carefully and with precise definitions. Defining the display of offensive messages as disorderly conduct likely will not pass constitutional muster, and laws that take such an approach may well be fatally overbroad, rather than appropriately tailored time, place, and manner regulations.

\section{The First Litigated Case: McQueary v. Stumbo ${ }^{104}$}

The first case to address the constitutionality of one of the recently enacted funeral picketing laws is McQueary v. Stumbo in which a federal district court declared two provisions of the Kentucky statute unconstitutional. Though the Kentucky statute has a number of provisions, the plaintiff and the court focused on the following two:

102. See Ward v. Rock Against Racism, 491 U.S. 781, 803 (1989) (upholding noise limitations for concerts in Central Park); Grayned v. Rockford, 408 U.S. 104, 120-21 (1972) (upholding a noise ordinance against constitutional challenge when applied to individuals engaged in a noisy demonstration near a school).

103. United States v. Grace, 461 U.S. 171, 180 (1983).

104. 453 F. Supp. 2d 975 (E.D. Ky. 2006). 
(1) A person is guilty of interference with a funeral when he or she at any time on any day:

(b) Congregates, pickets, patrols, demonstrates, or enters on that portion of a public right-of-way or private property that is within three hundred (300) feet of an event specified in paragraph (a) of this subsection; or

(c) Without authorization from the family of the deceased or person conducting the service, during a funeral, wake, memorial service, or burial:

1. Sings, chants, whistles, shouts, yells, or uses a bullhorn, auto horn, sound amplification equipment, or other sounds or images observable to or within earshot of participants in the funeral, wake, memorial service, or burial; or

2 . Distributes literature or any other item. ${ }^{105}$

The McQueary court ultimately struck down both provisions, though in the process it did reach some conclusions that are helpful to proponents of funeral picketing laws. The court first concluded that the plaintiff's facial challenge to the statute-without having been arrested for violating or charged with a violation of it - was appropriate under First Amendment doctrine. ${ }^{106}$ The court next discussed the First Amendment "overbreadth" doctrine in general, and then proceeded with two primary inquiries: (1) Is the Kentucky statute content neutral and, if so, (2) is the statute a constitutionally valid time, place, and manner regulation?

With respect to content neutrality, the court focused on the "government's predominate purpose" as the test. ${ }^{107}$ The court found "it is clear" that passage of the Kentucky law was "motivated by a specific desire to restrict the [Westboro Baptist Church's] ability to demonstrate at soldiers' funerals." 108 And the court found that the State's asserted concern about avoiding "potentially violent confrontations" at funerals was a content-based motive. ${ }^{109}$ But, importantly, the court also concluded that the law is content neutral to the extent "the provisions at issue were predominately motivated by the need to prevent all

105. Ky. ReV. Stat. AnN. § 525.155(1)(b)-(c) (West, Westlaw through 2006 Reg. Sess. and 1st Ex. Sess.).

106. McQueary, 453 F. Supp. $2 \mathrm{~d}$ at $979-81$.

107. Id. at 983 .

108. Id. at 984 .

109. Id. at 985 . 
interferences with all funerals regardless of the content or creator of the interference."110 This left the court with findings of mixed legislative motives - some content-based and others not-but the court pointed out that the language of the statute applies "evenhandedly to all speakers.",111 Thus, the court ultimately concluded that the Kentucky statute could and should be viewed as content neutral. ${ }^{112}$

The finding of content neutrality directed the court to its second major inquiry-whether the Kentucky statutory provisions are valid time, place, and manner regulations. The court first observed that the 300-foot buffer zone in the Kentucky statute necessarily would include both traditional public fora and private property. ${ }^{113}$ For that reason, any valid time, place, and manner regulation would have to (1) serve a significant state interest, (2) be narrowly tailored, and (3) leave open ample alternative avenues of communication.

The court began with the question whether the Kentucky law serves significant state interests. The court surveyed many of the cases discussed previously in this Article-including Cohen, Frisby, Madsen, and Hill-and focused on the Government's interest in protecting citizens from unwanted communications. Though ultimately somewhat skeptical that the State's interest in protecting the area surrounding funerals from unwanted communications is a significant one, the court did recognize that there are important privacy interests at stake and a sort of captive audience problem:

A funeral is a deeply personal, emotional and solemn occasion. Its attendees have an interest in avoiding unwanted, obtrusive communications which is at least similar to a person's interest in avoiding such communications inside his home. Further, like medical patients entering a medical facility, funeral attendees are captive. If they want to take part in an event memorializing the deceased, they must go to the place designated for the memorial event. Whatever the meaning of Hill, for purposes of this Opinion, the Court will assume that the state has an interest in protecting funeral attendees from unwanted communications that are so obtrusive that they are impractical to avoid. ${ }^{114}$

The court's ultimate resolution of the case, however, turned on the next inquiry-whether the Kentucky provisions were narrowly tailored.

\footnotetext{
110. Id.

111. Id.

112. $I d$. at $985-86$.

113. Id. at 986 .

114. Id. at 992 .
} 
The court found that in several ways they were not. For instance, the court opined that the relevant provisions prohibited speech whether or not protesters were even visible to funeral attendees, whether or not the speech could be heard by attendees, and whether or not attendees might easily avoid the speech. ${ }^{115}$ Further, the court concluded that the 300 -foot buffer zone was "substantially larger" than any buffer zone the Supreme Court has approved in prior cases, and necessarily would restrict speech in both traditional public fora and on private property (by the property owners themselves). ${ }^{116}$ Lastly, the court concluded that it could not give the statute a limiting construction that might save it. ${ }^{117}$ Thus, the court found the two provisions at issue to be unconstitutionally broad.

There are a few interesting points about McQueary. First, the court seemed to have a much more difficult time concluding that the statute was content neutral than probably ought to be the case. The McQueary court literally examined legislative motives, an inquiry that is always risky for courts. Had the court simply focused on the language of the statute and the activities it actually regulates, the content neutrality determination is clear and much easier. In general, there is no good reason for courts to get bogged down in potentially tricky evaluations of legislative motives, and perhaps especially not in a context such as this one. ${ }^{118}$ Indeed, many statutes are enacted in response to particular situations or problems but, so long as their prohibitions are evenhanded, that fact should not subject them to extraordinary constitutional scrutiny.

Second, the McQueary court seems plainly skeptical, or at least wary, of finding a significant state interest in protecting the privacy of funeral attendees. As discussed above, this is an important question in this context, and there is no Supreme Court precedent directly on point. That said, the privacy at stake in the funeral context is at least arguably of a higher order than privacy interests the Court has recognized in schools, courthouses, and polling places - all contexts in which the Court has upheld some restrictions on unwanted communication.

\footnotetext{
115. Id. at $994-95$.

116. Id. at 996 .

117. Id. at 997 .

118. Indeed, in this context, the Supreme Court has indicated reluctance at times to look beyond the face of a statute in determining content neutrality. For example, in City of Los Angeles $v$. Alameda Books, Inc., 535 U.S. 425 (2002), Justice Kennedy in his concurring opinion warned that "whether a statute is content neutral or content based is something that can be determined on the face of it." Id. at 448 (Kennedy, J., concurring). See also Hill v. Colorado, 530 U.S. 703, 725 (2000) (determining there is no basis for finding a statute viewpoint based "simply because its enactment was motivated by the conduct of the partisans on one side of a debate").
} 
Lastly, the McQueary court appears to be on very solid ground in questioning whether a 300-foot buffer zone with no exceptions for traditional public fora or the use of private property by owners is narrowly tailored. None of the Supreme Court's decisions approve any buffer zone remotely approaching such size, nor do the Court's opinions suggest it would look favorably upon such significant buffer zones. Moreover, the McQueary court correctly focuses on the Kentucky provisions' failure to limit their prohibitions to unreasonable or intrusive noise, a clearly constitutional option. In defense of Kentucky, the statute in fact has several other provisions which the plaintiff did not challenge and which likely are constitutional because they are much more narrowly tailored. ${ }^{119}$

Another federal district court recently addressed Missouri's somewhat different funeral picketing law, but only in a tentative ruling denying the plaintiff's request for a preliminary injunction. In PhelpsRoper v. Nixon, ${ }^{120}$ the court considered a Missouri statute that prohibits picketing "in front of or about" a funeral. The court denied the plaintiff's request for a preliminary injunction against enforcement of the law, finding that the statute was content neutral on its face and that the plaintiff had failed to establish that the law was likely to fail time, place, and manner regulation requirements. ${ }^{121}$ Interestingly, the Nixon court appeared to find the "in front of or about" prohibition less problematic than an actual, defined buffer zone, such as within 300 feet of a funeral location-which was Missouri's fallback enactment. ${ }^{122}$

119. For instance, other provisions prohibit "violent, tumultuous, or threatening behavior," "unreasonable noise," or creating a "physically offensive condition." KY. REV. STAT. ANN. § 525.055(1)(a) (West, Westlaw through 2006 Reg. Sess. and 1st Ex. Sess.). But one other provision of the legislation not challenged in McQueary seems highly questionable. See Ky. REV. STAT. AnN. $\S 525.145$ (1) (West, Westlaw through 2006 Reg. Sess. and 1st Spec. Sess.) (declaring that a person is guilty of disrupting meetings and processions when, with intent to disrupt, he "makes any utterance, gesture, or display designed to outrage the sensibilities of the group attending the occasion").

120. No. 06-4156-CV-C-FJG, 2007 WL 273437 (W.D. Mo. Jan. 26, 2007).

121. Id. *2-*4.

122. See id. at *4 (holding that the phrase "in front of or about" had a clear meaning and was not unconstitutionally vague). Even more recently, a federal district court in Ohio denied a request for a preliminary injunction against the Ohio funeral picketing law's 300-foot buffer zone around funerals, but granted a preliminary injunction with respect to the Ohio law's "floating" 300 -foot buffer zone around funeral processions. Phelps-Roper v. Taft, No. 1:06 CV 2038, 2007 WL 915109, *6-*7 (N.D. Ohio, Mar. 23, 2007). 


\section{E. A Note on the Federal Acts}

The federal funeral picketing laws may have constitutional advantages that the state laws lack. First, the federal acts are more narrowly tailored in some respects than most of the state laws. Federal law creates a 150-foot buffer along roads, pathways, or other routes of ingress and egress in which speech activities are restricted. It also creates a 300 -foot buffer simply for purposes of ensuring access to and egress from federal cemeteries. Thus, it appears that the buffer zone which actually limits speech activities is 150 feet, much smaller than most state law buffer zones (though not all). ${ }^{123}$

Second, the federal acts arguably serve unique federal interests that are not available to justify the state laws. First, to the extent the federal acts apply to cemeteries under federal control, they are controlling only federal property over which, by definition, the federal government has extensive control and extensive ability to regulate, especially since cemeteries themselves are nonpublic fora. The issue, of course, is to what extent Congress may restrict expressive activity on public fora adjacent to such cemeteries, and here the analysis is trickier.

In the context of military bases, the Supreme Court has declined to find that streets open to the public on such bases are traditional public fora. ${ }^{124}$ Rather, as the Court declared, it is the business of the military "to train soldiers, not to provide a public forum." "25 Thus, an argument might be made that the streets and sidewalks adjacent to and within federal cemeteries likewise are not to be considered traditional public fora, giving Congress leeway to regulate their use.

But whether federal cemeteries can or would be analogized to military bases in this context is an open and potentially important question. There also are cases that make clear that federal property in

123. The federal acts' definition of a "demonstration" prohibited within the buffer zone however, may raise some potential constitutional questions. For instance, "demonstration" includes "any picketing or similar conduct." Respect for America's Fallen Heroes Act, Pub. L. No. 109-228, $\S 2(a)(1)(b)(1), 120$ Stat. 387, 388. Such conduct is included apparently irrespective of whether such activity is completely quiet and peaceful. And it prohibits "[a]ny oration" or "speech" that is "not part of a funeral, memorial service, or ceremony," id. §2(a)(1)(b)(2), again, irrespective of whether such speech is audible to mourners or in any way actually intrudes on a service. And the federal act permits the "display of any placard, banner, flag or similar device [if] such a display is part of a funeral, memorial service, or ceremony," $i d$. $\S 2(a)(1)(b)(3)$, presumably meaning that supporters of the mourners, at least if considered "invited guests," could display American flags, banners, and signs within the buffer zone.

124. Greer v. Spock, 424 U.S. 828, 838 (1976).

125. Id. 
general is not immune from the time, place, and manner doctrine. Notably, many years ago the Supreme Court struck down in part a federal statute that purported to limit speech activities on the public sidewalks surrounding the Supreme Court building. ${ }^{126}$

A second potentially important distinction between the federal acts and the state laws is the Supreme Court's longstanding deference to Congress on military matters. Even with the amendment to broaden the federal law's scope to all military funerals, Congress is arguably only regulating matters involving military affairs. The Court repeatedly has recognized that Congress has a special and primary role in that area as a result of Congress's explicit Article I powers. Thus, courts might read the federal acts as a legitimate and constitutionally authorized effort by Congress to regulate the conduct of military funerals, an area uniquely the bailiwick of Congress, with deference to be paid by the courts.

None of this is to suggest that the federal acts necessarily pass constitutional muster, but only that there may well be additional and unique justifications in support of the federal laws that simply do not apply to the state enactments.

\section{ThE Challenges of ENACTING CONSTITUTIONAL FUnERAL PICKETING ACTS}

\section{A. A Philosophical Question}

The funeral picketing laws raise the important philosophical question whether speech conveying deliberately hurtful messages - often referred to as hate speech-really deserves First Amendment protection at all. This is a fundamental question about the nature of our First Amendment and its protection of freedom of speech in America. The question is hardly novel, but it clearly arises in the context of the funeral picketing laws.

And, of course, a corollary problem if courts pursue a hate speech doctrine is what exactly constitutes hate speech? Are some deeply offensive messages still part of the public debate, even if ill-informed, bigoted, and offensive, or do they so exceed the bounds of societal acceptance that they are outside constitutional protection?

The Supreme Court thus far has declined to carve out a category of hate speech subject to greater restrictions. Indeed, for the most part, the Supreme Court effectively has refused to engage in picking and choosing

126. United States v. Grace, 461 U.S. 171, 183-84 (1983). 
between the acceptability or condemnation of any particular messages, whether the cases have involved racially or ethnically or otherwise derogatory speech, ${ }^{127}$ or even the burning of an American flag to convey disrespect for American government. ${ }^{128}$ The only exception appears to be a situation in which the speech effectively conveys an actual or true threat of violence and intimidation, not just offensiveness. ${ }^{129}$

Certainly, arguments can be and have been made that hate speech stands on different footing than much other potentially offensive speech and therefore should be subject to greater restrictions. ${ }^{130}$ But to this point, that is an academic and philosophical argument, one the Supreme Court has not yet accepted in the First Amendment context. Were such an argument to be adopted, it might well strengthen the justifications for the funeral picketing laws considerably, since the messages of the Westboro Baptist Church are more than just offensive- they are hateful and deliberately provocative with respect to their target audiences.

\section{B. Pragmatic Considerations}

\section{Attention to Hateful Messages}

Our very attention to the funeral picketers has fueled their "success." Had Americans and the media been able to ignore the picketers, it seems likely that their funeral protests would have ceased. But the fact that their activities generate such outrage-including so much new legislation-emboldens rather than discourages the Westboro Baptist Church. Thus, one easily could conclude that the enactment of state funeral picketing laws ironically has prolonged the practice of funeral picketing, rather than deterring or stopping it.

Newspapers and media outlets in Kansas are well aware that publicly criticizing the activities of the Westboro Baptist Church only seems to

127. See, e.g., R.A.V. v. City of St. Paul, 505 U.S. 377, 391 (1992) (striking down hate-speech ordinance that the Court concluded was not evenhanded and prohibited only the expression of certain viewpoints on certain topics); Nat'l Socialist Party v. Village of Skokie, 432 U.S. 43, 43-44 (1977) (allowing Nazis to march through a town that had many Jewish residents).

128. See Texas v. Johnson, 491 U.S. 397, 414-20 (1989) (holding that a "state's interest in preserving the flag as a symbol of nationhood and national unity" does not justify criminal conviction for engaging in political expression).

129. See Virginia v. Black, 538 U.S. 343, 364-66 (2003) (finding that it is constitutional to criminalize the burning of a cross with intent to intimidate or threaten).

130. See, e.g., FARBER, supra note 72, at 117-24 (briefly critiquing current treatment of hate speech and options for reform); Steven J. Heyman, Introduction to HATE SPEECH AND THE Constitution: The Development of the Hate Speech Debate, at xli-lxiii (Steven J. Heyman ed., 1996) (providing several arguments regarding the hate-speech debate). 
encourage the church's members. And the author recently attended a funeral for a deceased government lawyer at which the picketers were present. Rather than let the picketers upset them, family members and friends made clear during the service that the departed lawyer would have viewed the protesters' presence as a badge of honor. But adopting such an attitude toward the protesters is perhaps easier said than done, especially for families who have lost a son or daughter in military service.

In the long run, the most effective strategy of all may be simply to ignore the funeral picketers. Even assuming some versions of the funeral picketing laws ultimately are found to be constitutional, it seems unlikely than any sizeable buffer zone will pass muster. Thus, the best-case scenario may be that the funeral protesters are only a few hundred feet or less from the entrances to cemeteries and churches where funerals are being held. I do not claim to begin to understand fully how some of the families are grieving at such a time but, perhaps, upon seeing the protesters, the best response is a shake of the head and reflection on how those in our military services daily defend and protect the very freedom that protesters are exercising.

\section{Civil Rights Suits by Protesters}

Because of the "chilling effect" funeral picketing laws may have on protected speech, plaintiffs will not have to violate the laws in order to have standing to challenge them in court. ${ }^{131}$ Instead, with respect to all of the state laws (but not the federal statute), the protesters may bring suit under 42 U.S.C. $\S 1983$ (2000), a statute that gives any person aggrieved by the constitutional violations of state and local government actors a cause of action for money damages and injunctive relief. Further, under 42 U.S.C. $\S 1988$, any plaintiff who prevails in such a suit generally must be awarded attorney's fees, an award which is sometimes the tail that wags the dog, in the sense that the attorney's fee award may dwarf any damages claim. That result is likely to be true in the funeral picketing context, since the protesters have no intention of ever being arrested or jailed for violating the laws, and thus are unlikely ever to suffer any significant damages.

In recognition of the potential for $\S 1983$ suits and $\S 1988$ fee awards in successful suits, Congressman Todd Tiahrt of Kansas in the fall of

131. See, e.g., McQueary v. Stumbo, 453 F. Supp. 2d 975, 979-80 (E.D. Ky. 2006) (discussing the standard of review for a preliminary injunction). 
2006 introduced a bill to amend both statutes. Titled the "Sons and Daughters of America Act," Representative Tiahrt's bill would make two primary amendments: (1) it would limit the remedies available in a $\S$ 1983 suit involving funeral "picketing, protesting, or demonstrating" to injunctive and declaratory relief (i.e., no damages allowed); and (2) no attorney's fees could be awarded under $\S 1988$ in such cases. ${ }^{132}$ Furthermore, the proposal includes a section prohibiting the awarding of attorney's fees in any lawsuits challenging federal funeral picketing laws. ${ }^{133}$

This proposal attempts a very lawyerly approach to the situation, but it may be both unconstitutional and a bad idea from a policy standpoint. As for constitutionality, the Constitution may not compel Congress to create a civil cause of action for plaintiffs whose constitutional rights have been violated by state or local officials. But if Congress does so, equal protection principles may well require Congress to create an evenhanded cause of action, a law that does not single out one particular constitutional right (free speech in the funeral context) for disfavored treatment. ${ }^{134}$

132. H.R. 6157, 109th Cong. § 2 (2006); see also Appendix C, infra Part IX (containing the entire text of the bill). Amusingly, the preamble to the bill reads " $[\mathrm{t}] \mathrm{o}$ amend the Revised Statutes of the United States to provide for legal protection against frivolous lawsuits directed at statutes prohibiting picketing at military and other funerals." H.R. 6157 pmbl. (emphasis added). The irony, of course, is that if the funeral picketing laws in fact violate the First Amendment, a lawsuit challenging them is hardly frivolous. But if, instead, the lawsuits are frivolous, then plaintiffs will not prevail and there is no basis for awarding either damages or attorney's fees under sections 1983 and 1988 anyway, so there is no need to change the law.

133. Section 1983, with its requirement that the offending officials act "under color of" state law, does not apply to the enforcement of federal law. Presumably, a suit against federal officials would be brought as a Bivens action in federal court, as an implied right of action arising under the First Amendment. See Bivens v. Six Unknown Unnamed Agents, 403 U.S. 388, 390 \& n.1 (1971) (finding that the complaint did state a cause of action under the Fourth Amendment because the complaint alleged that the arrest was done "unlawfully, unreasonably and contrary to law"). Or, a claim of unconstitutionality would arise as a defense to a criminal prosecution for violation of the federal act. Cf. United States v. Grace, 461 U.S. 171, 173-74 (1983) (hearing a suit regarding the unconstitutionality of a federal statute from two petitioners who were subject to arrest for their actions). But, in either event, the American Rule is that each party generally bears its own attorney expenses, and the only real exception is when a statute — such as $\S 1988$ — explicitly authorizes fee awards. The general understanding seems to be that attorney's fees are not available in Bivens actions, precisely because there is no statutory authorization for them. And it is not apparent that any other federal statute would authorize such fees in the context of challenging the federal funeral picketing law. So Representative Tiahrt's proposal may be a nullity and unnecessary in this regard. Furthermore, the Congressman's proposal does not purport to limit or preclude awards of damages in suits against the United States or federal officials, see H.R. 6157, §3, so it is not clear that his proposal would have any effect whatsoever on current law that otherwise would apply in litigation challenging the federal act.

134. Funeral picketers apparently are not the only target of congressional proposals to amend and limit sections 1983 and 1988. Another such effort passed the House of Representatives in late September 2006. Known as the Veterans' Memorials, Boy Scouts, Public Seals, and Other Public 
And even if such a lack of evenhandedness would not rise to constitutional magnitude, is it a good idea to start legislating such exceptions to the enforcement and protection of our constitutional rights, in effect legislatively creating a hierarchy of constitutional rights based on the will of political majorities? The notion that Congress can legislate away citizens' ability to enforce particular constitutional rights seems contrary to the very nature of our constitutional structure and separation of powers.

\section{A Constitutional Funeral Picketing Act?}

What is the result of all of the preceding discussion and analysis? Is it possible to enact a constitutional funeral picketing law? The short answer is yes. The longer answer is that it may not, however, be a law that fully satisfies those seeking to curb or silence the protesters.

First, it is constitutional to prohibit noise or physical interference that actually disrupts or disturbs a funeral or memorial service. Second, it is constitutional to ensure unimpeded access to and egress from a funeral or memorial service. Third, given the substantial privacy interests at stake in the context of a funeral, and the at least somewhat captive nature of the mourners who attend, some kind of limited, tailored buffer zone likely is constitutionally acceptable. Beyond these propositions, everything becomes arguable.

And even relying on the foregoing three propositions, there are not necessarily clear answers as to how to enact a constitutional law. Guaranteeing access is constitutional, but the more difficult question is how to do so? And even assuming some buffer zone is constitutional, certainly anything greater than 100 feet seems inherently suspect under the Supreme Court's cases, and there is no clear indication in those cases that even 100 feet will pass muster.

Thus, my best advice to those considering the enactment of, or defending the implementation of, any of the funeral picketing laws is to focus on the foregoing three principles and to enact or defend the narrowest law that one's constituencies can tolerate.

Expressions of Religion Protection Act of 2007, H.R. 725, 110th Cong. (2007), that bill "would bar courts from awarding any [§ 1988] attorney['s] fees to plaintiffs who successfully challenge government expression or endorsement of religion" under the First Amendment's Establishment Clause. David A. Drachsler, In Bad Faith, Legal Times, Oct. 16, 2006, at 58, 59. 


\section{CONCLUSION}

Though it may be a bedrock principle of the First Amendment that "government may not prohibit the expression of an idea simply because society finds the idea itself offensive or disagreeable," 135 it similarly is a bedrock principle that people need not hear or tolerate every message no matter where conveyed. ${ }^{136}$ Thus, some careful and thoughtful restrictions on funeral picketing may pass constitutional muster.

But emotional reactions written into law as zealous restrictions may only line the protesters' pockets with attorney's fees if and when the courts strike down unconstitutional laws. And, even assuming that only constitutional laws are enacted, a serious question remains whether such legislation actually furthers the goal of dissuading the protesters from their offensive and provocative actions. The more attention the Westboro Baptist Church receives, the more likely its members are to continue and even to expand their activities. Paying them no notice whatsoever, or viewing their presence near a funeral as a sort of badge of honor for the deceased and the mourners, would be the truest triumph of all. And unquestionably constitutional.

135. Texas v. Johnson, 491 U.S. 397, 414 (1989).

136. See Frisby v. Schultz, 487 U.S. 474, 488 (1988) (holding that a prohibition on picketing was valid because it protected individuals who were "presumptively unwilling to receive it"); Rowan v. U.S. Post Office Dept., 397 U.S. 728, 737 (1970) (finding that a right to communicate advertisements to an individual's home is "circumscribed . . by an affirmative act of the addressee . .. that he wishes no further mailings"). 


\section{TABle 1: State Funeral Picketing LAWS}

Many States have adopted or considered funeral picketing laws. States which have adopted funeral picketing laws are indicated with bold print. 
VII. APPENDIX A 
VIII. APPENDIX B 
[Vol. 55

IX. APPENDIX C 
